\title{
NÁLEZ ŽIDOVSKÉ RITUÁLNÍ LÁZNĚ - MIKVE - V CHRUDIMI. ZÁCHRANNÝ ARCHEOLOGICKÝ VÝZKUM NA JÁNSKÉM PŘEDMĚSTÍ V ROCE 2013
}

\author{
JAN FROLÍK - MONIKA PECINOVSKÁ - JANA VEPŘEKOVÁ
}

\begin{abstract}
Abstrakt: Příspěvek seznamuje s výsledky záchranného archeologického výzkumu na bývalém Jánském predměstí východočeského města Chrudimi. Kontinuálni osídlení je doloženo od 13. století na ploše pěti parcel se zástavbou v pěti až šesti chronologických etapách. Hmotná kultura města a předměstí se podle nálezů v obdobi 15. až 18. století nelišila. Významným nálezem je odkrytí židovské rituální lázně - mikve, datované na základě pisemných zpráv pred rok 1656, resp. 1660, a pravděpodobně uživané od 16. století.
\end{abstract}

Klíčová slova: Chrudim - archeologie - Židé-mikve-predměstí.

The Find of the Mikveh Jewish Ritual Bath in Chrudim. Rescue archaeological research in the Jánské předměstí suburb in 2013

Abstract: This contribution presents the results of rescue archaeological research in the former Jánské predměsti suburb in the town of Chrudim, eastern Bohemia. Continuous settlement has been recorded there from the 13th century in the area of five built-up plots, in five or six chronological phases. Judging by the finds, the material culture of the town and the suburb did not differ in the 15th-18th centuries. One major find was the mikveh Jewish ritual bath dated, on the basis of written sources, before the years 1656/1660, and probably used from the 16th century onwards.

Key words: Chrudim - archaeology - Jews - mikveh - suburb.

\section{1 Úvod}

Město Chrudim je od 80. let 20. století objektem soustředěného záchranného archeologického výzkumu, který přinesl zásadní poznatky k pravěkým i raně středověkým etapám osídlení (Frolík 2006; 2012). Dva velké plošné záchranné archeologické výzkumy (Filištínská ul. čp. 37/ IV-41/IV, Hradební ul. čp. 10/IV, 14/IV-15/IV - Frolík-Musil 2010) přinesly množství poznat-

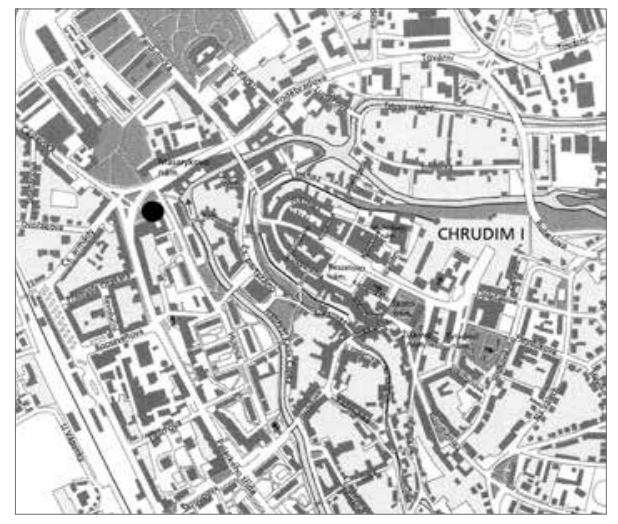

Obr. 1. Chrudim. Centrum města s vyznačením polohy výzkumu. Abb. 1. Chrudim. Stadtzentrum mit eingezeichneter Lage der Grabung. ků $\mathrm{k}$ počátkům vrcholně středověkého města a jeho vývoji, ale také poznání předchozích raně středověkých etap, spojených s existencí hradiště a posléze existencí přemyslovského správního centra (Frolík-Sigl 1995; 1998; 1998a). Poněkud stranou zůstávalo poznání středověkých chrudimských předměstí (Nové Město, Kateřinské prredměstí, Jánské předměstí, Putrkasy). Jednou z příčin byla skutečnost, že jejich značné části (především na Kateřinském a také Jánském předměstí) podlehly v 70. a 80. letech minulého století plošným demolicím a cílený záchranný archeologický výzkum do nich vstoupil až na samém konci asanačních aktivit (Frolík-Sigl 1984; 1990; 1996; 1997). Rozmach výstavby po roce 1989 se nejprve soustředil na městské jádro, eventuálně na volné příměstské plochy.

Změnu přinesl rok 2013, kdy byla zahájena rekonstrukce největšího chrudimského hotelu Bohemia na kongresové centrum. Součástí stavebních aktivit bylo také zvětšení parkovací kapacity vybudováním podzemních garáží. Jejich plocha byla proto podrobena záchrannému archeologickému výzkumu. 


\section{Archeologický výzkum}

Prostor budoucích garáží je situován v parčíku na Masarykově náměstí (č. parc. 190/1, 190/2 a 190/3) před budovou hotelu (obr. 1). Parčík vznikl na místě zástavby demolované na konci 60. let 20. století. Hotel byl postaven v zahradách demolovaných domů, plocha parčíku byla na místě jejich dvorů a dvorní části zástavby. Průčelní části parcel s původními domy se dnes

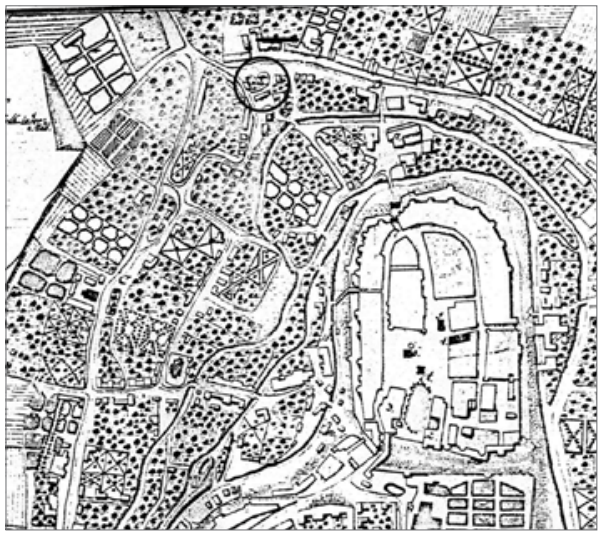

Obr. 2. Chrudim. Plán města z období 1732-1790. Domy čp. 37/ IV a 38/IV jsou zachyceny jako samostatný blok (zvýrazněno kroužkem).

Abb. 2. Chrudim. Stadtplan aus der Zeit von 1732-1790. Die Häuser mit den Konskriptionsnummern 37/IV und 38/IV wurden als selbständiger Block erfasst (als Kreis hervorgehoben)

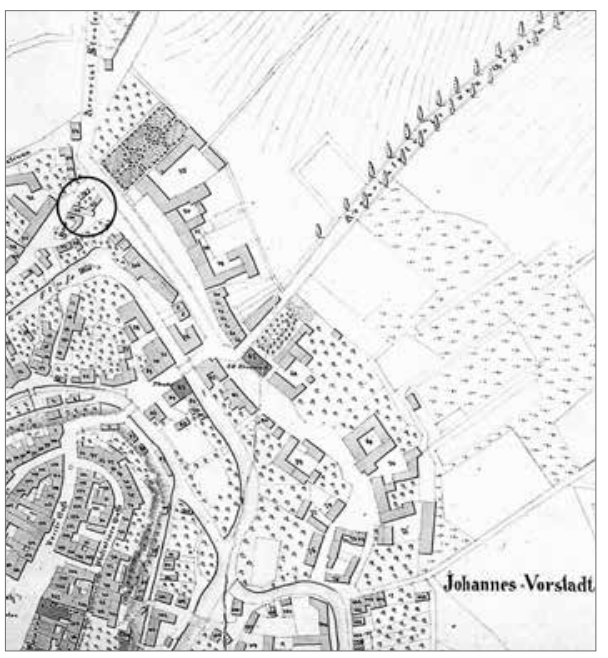

Obr. 3. Chrudim. Plán Jánského předměstí z roku 1847. Domy čp. 37/IV, 38/IV a 39/IV tvoří samostatný blok (zvýrazněno kroužkem).

Abb. 3. Chrudim. Plan der Johannesvorstadt aus dem Jahr 1847. Die Häuser mit den Konskriptionsnummern 37/IV, 38/ IV und 39/IV bilden einen selbständigen Block (als Kreis hervorgehoben). převážně nacházejí pod rozšířenou vozovkou Masarykova náměstí a Palackého ulice. Zkoumaný areál se historicky nachází na středověkém chrudimském Jánském předměstí, a to v sousedství jeho centrální plochy (dnešní Masarykovo náměstí). $Z$ východní strany byla plocha výzkumu vymezena ústím Husovy ulice do Masarykova náměstí. Její původní zakončení bylo až do výstavby hotelu tvořeno vidlicí, jejíž východní větev se zachovala (obr. 2-4). Západní, která směřovala z jihovýchodně položeného Kateřinského předměstí a pokračovala západním směrem na Č́slav, při výstavbě hotelu zanikla.

Přímo ze zkoumané plochy nebyly známy žádné starší archeologické nálezy. $Z$ výkopu na protější straně náměstí byly získány mladohradištní záušnice, ze staveniště východně od zkoumané plochy keramika ze 13. století (Frolík-Sigl 1995, 88-89). Z blízkosti zkoumané plochy také mohou pocházet celé nádoby mladohradištního stáří a ze 13. století, uložené bez přesnější lokalizace ve sbírkách chrudimského muzea (Frolík 1980), a z blízkého okolí pocházel také dnes nezvěstný soubor středověké a pozdně středověké keramiky (Florián 2014).

Zkoumaná plocha byla rozměřena do 108 sektorů o velikosti $3 \times 3 \mathrm{~m}$, z toho dvanáct bylo vypuštěno pro úplné zničení recentním teplovodem. Rozšíření původního záměru představoval záchranný výzkum $\mathrm{v}$ trase přeložky plynovodu, která lemovala zkoumanou plochu na západní, severní a zčásti východní straně. Celkově bylo evidováno 6730 sáčků archeologického materiálu, bylo odhaleno 180 zdí, 1203 výkopů a dokumentováno 3038 uloženin (obr. 5). Výzkum proběhl v období od 6. března do 17. července 2013 ve spolupráci s firmou Osina Archeo s.r.o. a Regionálním muzeem v Chrudimi, které se ujalo laboratorního zpracování a evidence.

Zkoumaná plocha je součástí Chrudimské tabule. Pozemek se nachází v holocenní nivě řeky Chrudimky. Podloží tvoří rozličné formy fluviálních sedimentů. Na něm se vyvinula půda typu podzolu. Zřejmě až v raném středověku byl terén rozčleněn erozními (výmolovými) povodňovými koryty. Takto vzniklé deprese byly 


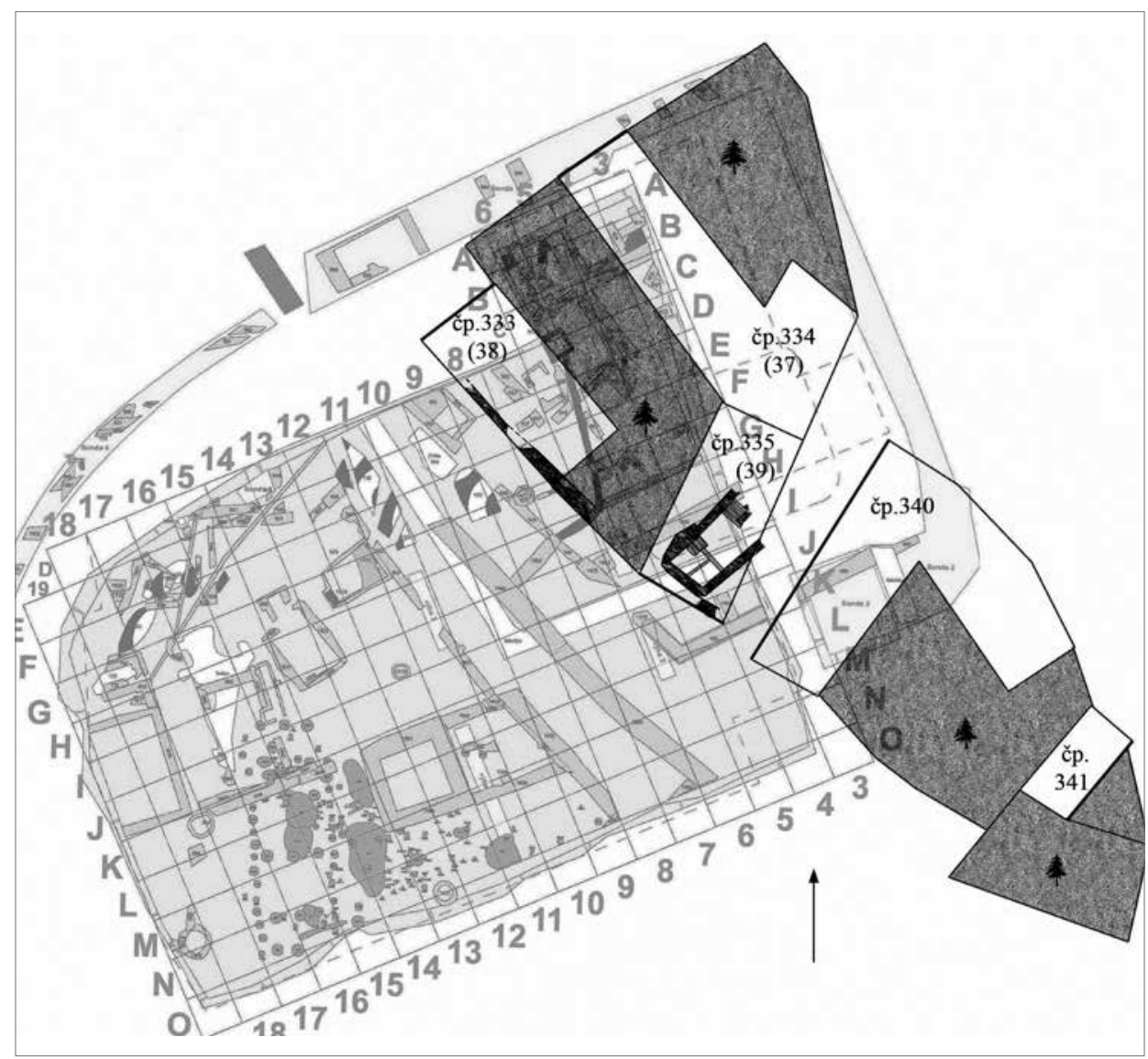

Obr. 4. Chrudim. Nejstarší zděná stavební etapa v bloku domů 37/IV až 39/IV vkreslená do mapy stabilního katastru z roku 1839; v ploše pozdějšího čp. 39/IV sklep s rituální lázní (mikve). Dům se sklepem je orientován vůči ulici odlišně než zástavba z roku 1839. Vypracovala J. Vepřeková.

Abb. 4. Chrudim. Älteste Wand der Bauetappe in Häuserblock 37/IV bis 39/IV eingezeichnet in einer Karte des Stabilen Katasters aus dem Jahr 1839; auf der Fläche der späteren Konskriptionsnummer 39/IV Keller mit rituellem Tauchbad (Mikwe). Das Haus mit dem Keller hat zur Straße hin eine andere Lage als die Bebauung aus dem Jahr 1839. Erstellt von Vepřeková.

vyplňovány bahnitými a hlinitými sedimenty. Během novověku byly deprese vyplněny navážkami. Nejvýraznější povodňové koryto probíhalo zkoumanou plochou přibližně uprostřed ve směru východ-západ a rozdělilo původní půdní pokryv na dvě nezávislé plochy (Šušolová-Hadacz 2013; Zavřel 2013).

Na zkoumané ploše bylo překvapivě zjištěno pravěké osídlení. Nejstarší etapu tvořila okrajová část neolitického sídliště, které bylo využíváno minimálně ve dvou etapách (střední/mladší stupeň kultury s lineární keramikou, šárecký stupeň), pravděpodobně ještě i v období lengyelského zásahu. Pro obě etapy kultury s lineární keramikou je doložen dlouhý dům. Neolitické osídlení zanechalo na místě kulturní souvrství, členěné na dvě úrovně odpovídající dvěma základním chronologickým komponentám. Pozoruhodným jevem je umístění naleziště, které není situováno na sprašovém podloží, jak by bylo obvyklé, ale na holocenní podzolové půdě. Neolitická komponenta se dochovala $\mathrm{v}$ jižní části zkoumané plochy. V části severní spadá nalezená kulturní vrstva se zlomky keramiky do doby bronzové. Na místě původního neolitického osídlení byly registrovány také nepočetné nálezy středohradištní a mladohradištní (v tomto prŕípadě včetně nejméně jednoho objektu - Frolík-Pecinovská-Vepřeková 2014; 2014a). 


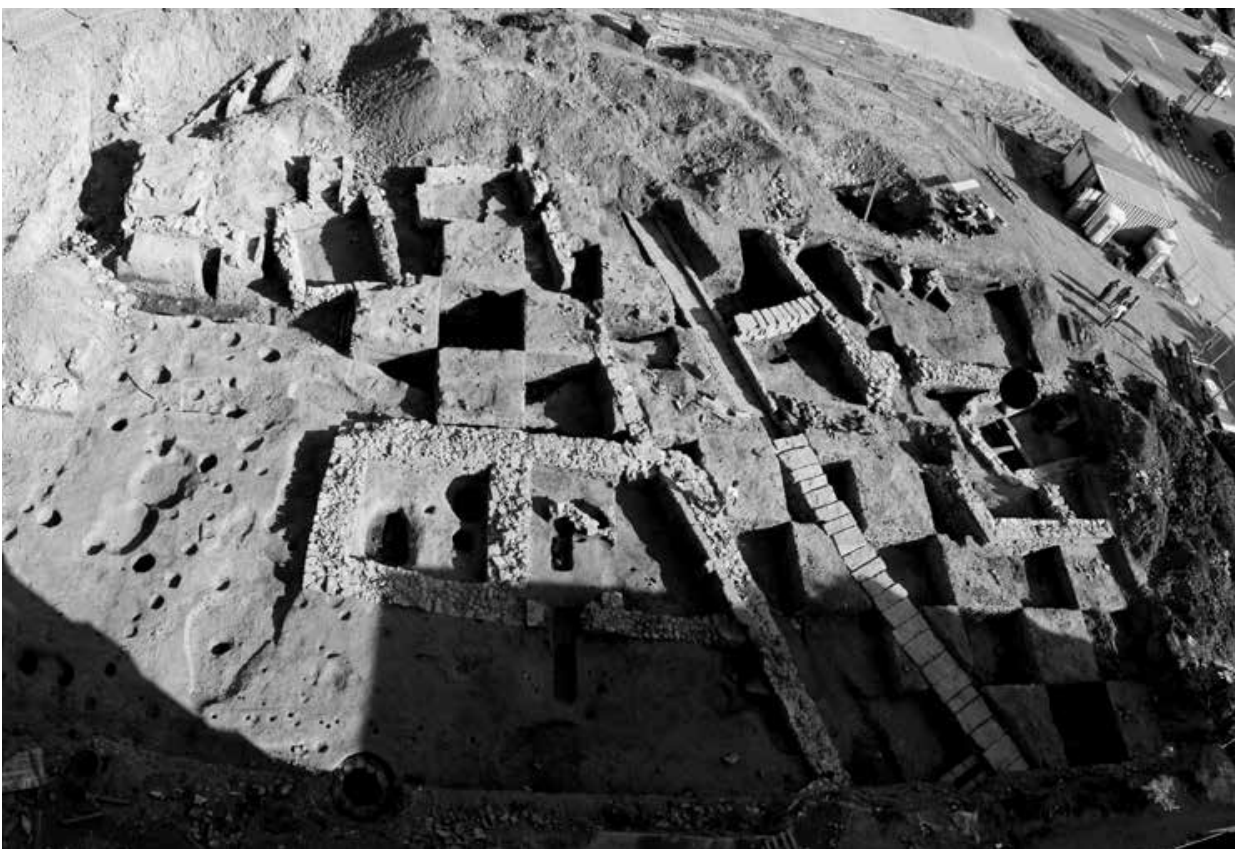

Obr. 5. Chrudim, Masarykovo náměstí. Pohled na zkoumanou plochu shora. Stavba s rituální lázní (mikve) leží u pravého okraje (zvýrazněno černým kroužkem). Foto J. Frolík.

Abb. 5. Chrudim, Masaryk-Platz. Blick auf die untersuchte Fläche von oben. Der Bau mit dem rituellen Tauchbad (Mikwe) liegt am rechten Rand (hervorgehoben mit schwarzem Kreis). Foto J. Frolík.

\section{Písemné zprávy}

Počínaje 13. stoletím byla zkoumaná plocha osídlena kontinuálně, i když písemné zprávy o zástavbě informují až od roku 1708. Podle písemných zpráv šlo celkově o pět nemovitostí (čp. 37/IV až 39/IV, 52/IV a 53/IV). Tři se nacházely v bloku ve výše zmíněné vidlici ulic, které tvořily ústí Husovy ulice (čp. 37/IV až 39/IV - obr. 4), dva západně od Husovy ulice (čp. 52/IV a čp. 53/IV).

Nejstarší dochovaná písemná zpráva se vztahuje k domu čp. 38/IV. V roce 1708 prodala chrudimská obec kus pustého místa „pro vystavění nějakého domku“ Jiřímu Pokornému. Ten pozemek získal pro svou dceru Annu Kudrnkovou, provdanou Píšovou. V roce 1722 dům stál, protože Anna Kudrnková/Píšová prodala domek vedle domu Jana Špáty a „svobodné cesty ze strany druhé“" Kryštofu Navrátilovi. V roce 1800 nemovitost tvořil dům se zahrádkou a studní. V roce 1850 vyhořel. Spáleniště koupili v roce 1855 manželé Rosovi a znovu ho zastavěli. V roce 1893 se poprvé zmiňuje hostinec, který v něm zůstal až do zboření.

Sousední dům čp. 37/IV se v písemných pramenech objevuje v roce 1721, kdy ho jeho majitel Jan Habrbouz prodal Janu Špátovi. Zahrada se zmiňuje v roce 1786, kdy byl ve vlastnictví Josefa Čmelíka a jeho manželky. I tento dům vyhořel v roce 1850 a musel být postaven znovu. Před zánikem v něm bylo řeznictví.

Jako poslední byl postaven dům čp. 39/IV, a to na kusu zahrady, který původně patřil k domu čp. 37/IV. Stalo se tak v roce 1803. Tento dům nebyl po požáru v roce 1850 obnoven a parcela byla připojena $\mathrm{k}$ nemovitosti čp. $38 / \mathrm{IV}$ a zastavěna hospodářskými budovami. Popisné číslo bylo přeneseno na jinou nemovitost.

V západní části staveniště se nacházely pozemky domů 52/IV a 53/IV, dotčené výzkumem pouze částečně, protože se většinou nachází pod dnešní vozovkou. Dům čp. 52/IV je písemně doložen jako nejstarší ze všech zkoumaných staveb. V roce 1707 byl jako dědictví prodán „domek“. 
Kdy byl postaven, však nevíme. V roce 1779 se popisuje jako „dům se stodolou a zahradou“. Tato charakteristika se pro 19. století mění na ,grunt se zahrádkou“. Sousední dům čp. 53/IV byl postaven po roce 1776 na části pozemku odprodaného od výše zmíněné nemovitosti. V roce 1788 se uvádí jako „domek se stodolou a zahrádkou“, později obdobně jako soused, tj. „grunt se zahrádkou". Obě nemovitosti byly postiženy požárem v roce 1850 a stavěny znovu. V̌̌echny nemovitosti byly (spolu s několika dalšími) zbořeny v letech 1967 až 1969 v rámci prŕpravy staveniště (všechny historické údaje podle Florián b. d.).

\section{Popis a interpretace nálezové situace}

Archeologický výzkum prokázal, že kamenná zástavba je mnohem staršího data než nejstarší písemné údaje. Vznikala již v 15. století a její rozvržení kopírovalo rozdělení do jednotlivých nemovitostí, které je doloženo v 18. až 19. století. Nejstarší stavební etapa byla stavěna $\mathrm{z}$ opuky na jíl a před požárem v roce 1850 vykazovala dvě až tři přestavby. Na přilehlých dvorcích byly zjištěno obvyklé vybavení (4 studny, 2 odpadní jímky). Objeveny byly také tři pece z 15. století, jámy nejasného účelu a množství kůlových jamek nejspíše po lehčích dřevěných stavbách. Zatím zpracované nálezy indikují řemeslo obyvatel pozdější nemovitosti čp. 52/IV jako hrnčířství. Početně je doložen také odpad ze zpracování kostí (výroba knoflíků nebo korálků). Povrch ulice mezi oběma bloky nemovitostí byl hojně zpevňován struskou, její původ však nemusí být místní (Frolík-Pecinovská-Vepřeková 2014a). Zpracování keramických a skleněných nálezů ukazuje, že se hmotná kultura předměstí i vnitřního města pro období 15 . až

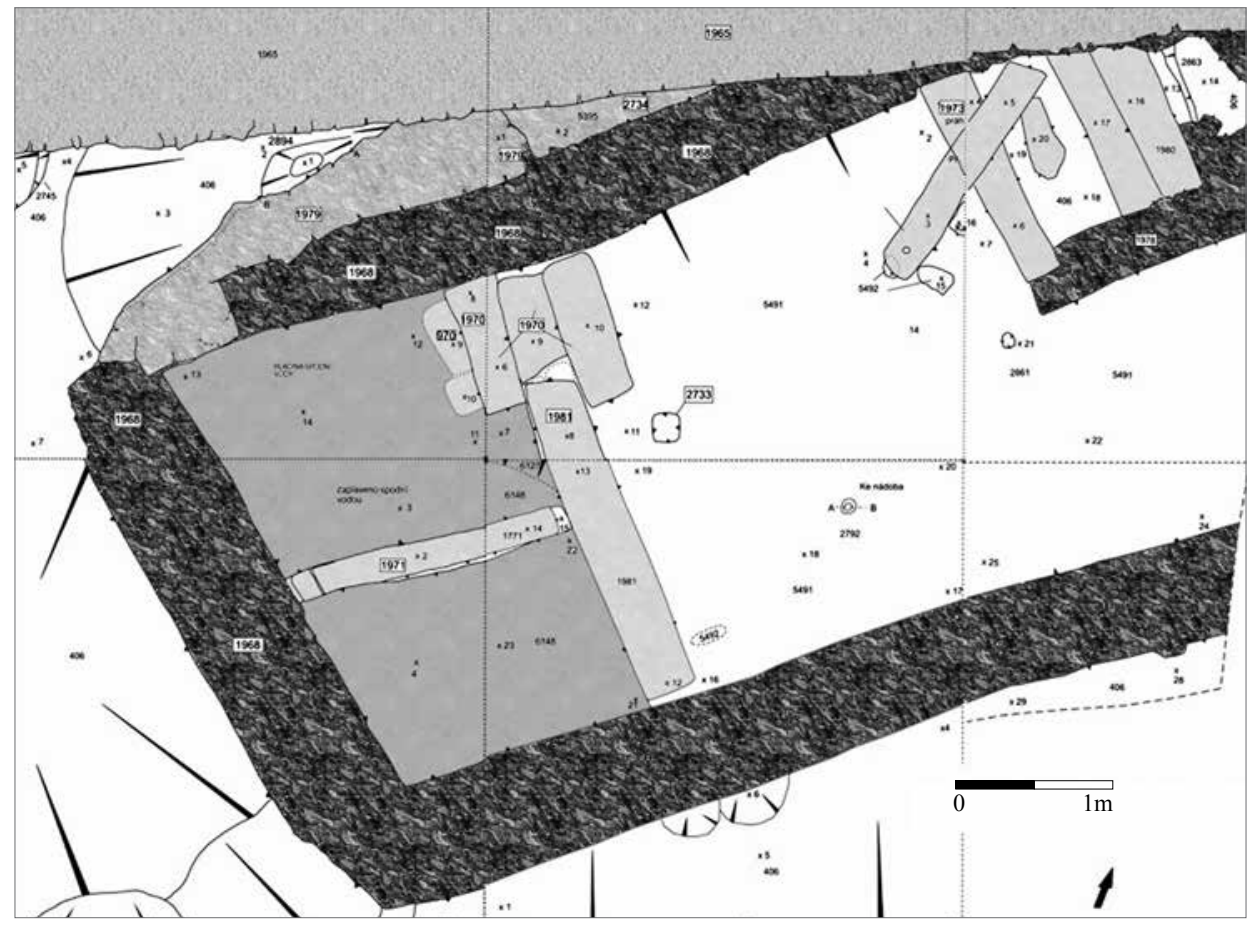

Obr. 6. Chrudim, Masarykovo náměstí. Půdorys stavby s rituální lázní (mikve). Černošedě a tmavě šedě obvodové zdivo sklepa (zdiva 1968, 1979); světle šedě přístupové schodiště do sklepa i se spadlou stojkou dveřního ostění (zdivo 1973) a obvodové zdivo lázně (zdivo 1981) s dělicí přepážkou (zdivo 1971) a schodištěm (zdivo 1970). Vypracovala J. Vepřeková.

Abb. 6. Chrudim, Masaryk-Platz. Grundriss des Baus mit rituellem Tauchbad (Mikwe). Schwarzgrau und dunkelgrau Außenmauern des Kellers (Mauerwerke 1968, 1979); hellgrau Kellertreppe mit umgestürztem Pfosten der Türlaibung (Mauerwerk 1973) und Außenmauern des Tauchbads (Mauerwerk 1981) mit Trennwand (Mauerwerk 1971) und Treppe (Mauerwerk 1970). Erstellt von J. Vepřeková. 
18. století nelišila, a to ani v zastoupení méně běžných nálezů (kamenina, keramické importy, malované sklo apod.).

Naše pozornost se soustředila na zajímavý nemovitý objekt, objevený u východního okraje výzkumu ve čtvercích I4, I5, J4 a J5 (obr. 6). Prozkoumaná terénní situace je relativně jednoduchá. Podložím je zde rezavě béžový jílovitý písek (uloženina 406), eventuálně světle šedý písčitý jíl s př́iměsí železitých konkrecí (uloženina 5491), na které nasedala vrstva charakteru původního půdního typu (uloženina 5207) či kulturní vrstvy (uloženiny 5395 a 6303), do které se zahluboval jámový objekt (výkop 2894). Do výplně tohoto objektu byly vyhloubeny kůlové jamky (výkopy 2835 a 2859). Všechny tyto objekty byly porušeny zdivem obdélného sklepa (zed' 1968). Zdivo bylo vyzděno z lomové opuky o šíŕi $0,6-0,65 \mathrm{~m}$. Zahloubeno bylo až $0,7 \mathrm{~m}$ pod úroveň podloží. Míru zahloubení oproti povrchu v době výstavby sklepa nelze pro narušení mladšími zásahy jednoznačně určit. Souvrství, do něhož mohl být sklep zapuštěn, se dochovalo v jeho blízkém okolí do úrovně maximálně $1 \mathrm{~m}$ nad dochovanou korunu zdiva. Dochované rozměry sklepa (délka a šířka) činí $6,1 \times 4,25 \mathrm{~m}$. Zatímco šířka je úplná, délka nikoliv. Objekt pokračuje východním směrem do neprozkoumané plochy. Nebyla však o mnoho větší. V severovýchodním rohu sektoru I4 bylo objeveno torzo kamenného prahu (zdivo 1973), na němž ležela spadlá stojka dveřního ostění. Nevelké rozšíření východním směrem (sektor I3) odhalilo dva schody (zdivo 1980), navazující na práh, ale nikoliv konec schodiště (zdivo 1976). Celkovou délku objektu lze odhadnout na 7,5 m. Nevíme však, zda je to úplná délka stavby, protože mohla pokračovat východním směrem mimo půdorys sklepa.

Podlaha sklepa byla tvořena pouze druhotně sníženým povrchem podloží (uloženina 5491). Stopy nějaké úpravy (dřevo, dlažba) zjištěny nebyly. Podle charakteru jednotlivých uloženin se zdá, že $\mathrm{z}$ doby existence sklepa je pouze hnědošedá jílovitopísčitá hlína s př́měsí uhlíků (uloženina 5449) o maximální mocnosti $0,1 \mathrm{~m}$. Místy byla překryta vrstvičkou okrového jílu s malou prŕíměsí uhlíků (uloženina 5476, mocnost až $0,08 \mathrm{~m}$ ). Do podlahy bylo vyhloubeno několik nevelkých kůlových jamek, které indikují zaniklé vnitřní zařízení (výkop 2792 - průměr $0,08 \mathrm{~m}$, hloubka $0,12 \mathrm{~m}, \mathrm{v}$ jamce byla zapuštěna nádoba [obr. 11:14]; výkop 2861 - průměr $0,08 \mathrm{~m}$, hloubka $0,1 \mathrm{~m}$; výkop 2733 - přibližně čtvercovitá $0,16 \times 0,16 \mathrm{~m}$, hloubka $0,16 \mathrm{~m}$ )

Výše uložené vrstvy vyplňující interiér sklepa mají odlišný charakter (hlinité uloženiny s př́íměsí uhlíků, mazanice a zlomků malty nebo opukových kamenů - 5394, 5422, 5423, 6281,

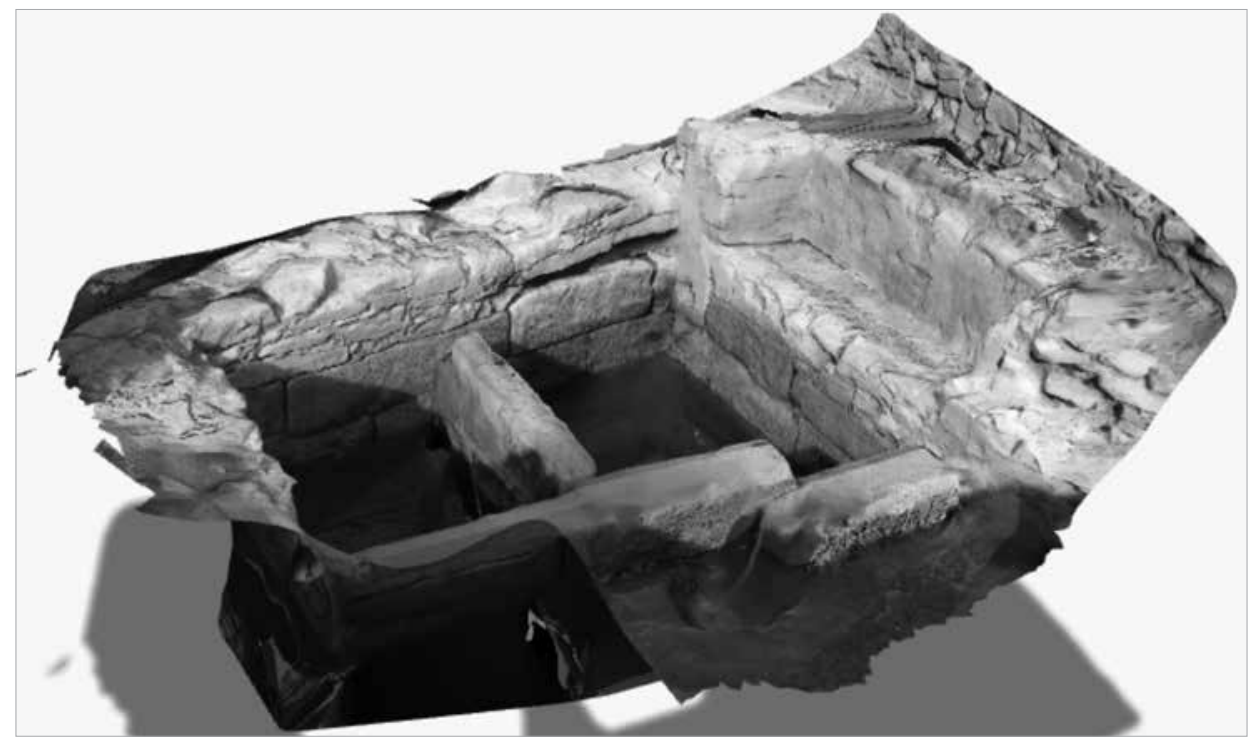

Obr. 7. Chrudim, Masarykovo náměstí. Sklep s rituální lázní (mikve) v 3D modelu. Vypracoval J. Unger.

Abb. 7. Chrudim, Masaryk-Platz. Keller mit rituellem Tauchbad (Mikwe) als 3D-Modell. Erstellt von J. Unger. 
6298, 6299, 6305, 6306). Dosahují úrovně koruny dochovaného sklepního zdiva. Terénní situace ukazuje, že stavba se sklepem byla zplanýrována a koruna zdiva překryta souvrstvím (uloženiny 5356, 6302), do kterého byly zapuštěny základy další stavební etapy na tomto místě (zdiva 1965, 1977 ve směru východ-západ). Vážné narušení původní situace znamenalo vyhloubení topného kanálu z 60. let 20. století, jehož výkop prot’al původní stavbu přibližně ve směru delší osy a odstranil původní souvrství přibližně do úrovně dochované koruny zdiva sklepa.

V západní části sklepa byla objevena dvoudílná vodní nádrž z rozměrných pískovcových kvádrů, eventuálně pískovcových ploten (obr. 6,7). Nádrž měla být od počátku integrální součástí sklepa, protože její stěny byly zakomponovány do stěn sklepa. Nad uvažovanou úrovní vodní hladiny pokračovaly stěny nádrže/sklepa lomovým zdivem. Vybudování nádrže jako plánované součásti sklepa naznačuje také odkládací nika v severní stěně sklepa nad nádrží o rozměrech $1,85 \times 0,5-0,55 \mathrm{~m}$ (obr. 8,9 ). Stěny niky byly původně hladce omítnuty. Nádrž měla vnitřní rozměr 2,9-3,1 × 1,55-2,2 m přizpůsobený nepravidelnému tvaru sklepa. Nádrž byla dvoudílná, rozdělená uprostřed přepážkou z pískovcových kvádrů a rozměrné plotny jako její koruny (zdivo 1971). Šířka přepážky činí $0,2 \mathrm{~m}$. Při stěnách byly v koruně přepážky pravoúhlé výřezy o rozměrech $0,15 \times 0,15 \mathrm{~m}$ (obr. 9,10$)$. Účel výřezů není jasný. Mohly sloužit jako přepad mezi oběma částmi nádrže. Druhou možností je, že jižní část nádrže byla překryta (dřevěnou deskou, která ležela na dvou trámcích). Dokládají to dva otvory v jižní stěně s rozměry blízkými výřezům v dělicí přepážce (obr. 10). Východní stěna nádrže byla završena dlouhým pískovcovým kvádrem o šířce $0,35 \mathrm{~m}$ (zdivo 1981). Nádrž byla přístupná v severovýchodním rohu schodištěm, tvořeným třemi stupni z pískovce (obr. 9). Šírka schodiště je $0,7 \mathrm{~m}$, výška jednotlivých stupňů je $0,24 \mathrm{~m}, 0,24 \mathrm{~m}$ a $0,2 \mathrm{~m}$. Na pravidelně vyzděné stupně navazuje ještě čtvrtý, nejnižší, vytvořený ze dvou rozměrnějších, ale nepravidelných bloků, přisazených k poslednímu stupni. Jeho výška činí 0,25 m. Celková hloubka nádrže je 0,93-1,01 m.

Podlaha nádrže byla pevná. Její přesný charakter se kvůli stálému př́ítoku vody však určit nepodařilo. Po skončení užívání byly obě části nádrže vyplněny hlinitými vrstvami s příměsí kamenů (uloženiny 6127 a 6148) o mocnosti přesahující $0,9 \mathrm{~m}$. Vzhledem k umístění v nádrži jsou tyto vrstvy odděleny od vrstev vyplňujících zbylý interiér sklepa. Souvrství související s mladší stavební etapou, které je př̌ekrývá (uloženiny 5356, 5448, 6152), svým průběhem naznačuje, že po opuštěném sklepě zůstala na místě výrazná proláklina. Místo zůstalo nezastavěné až

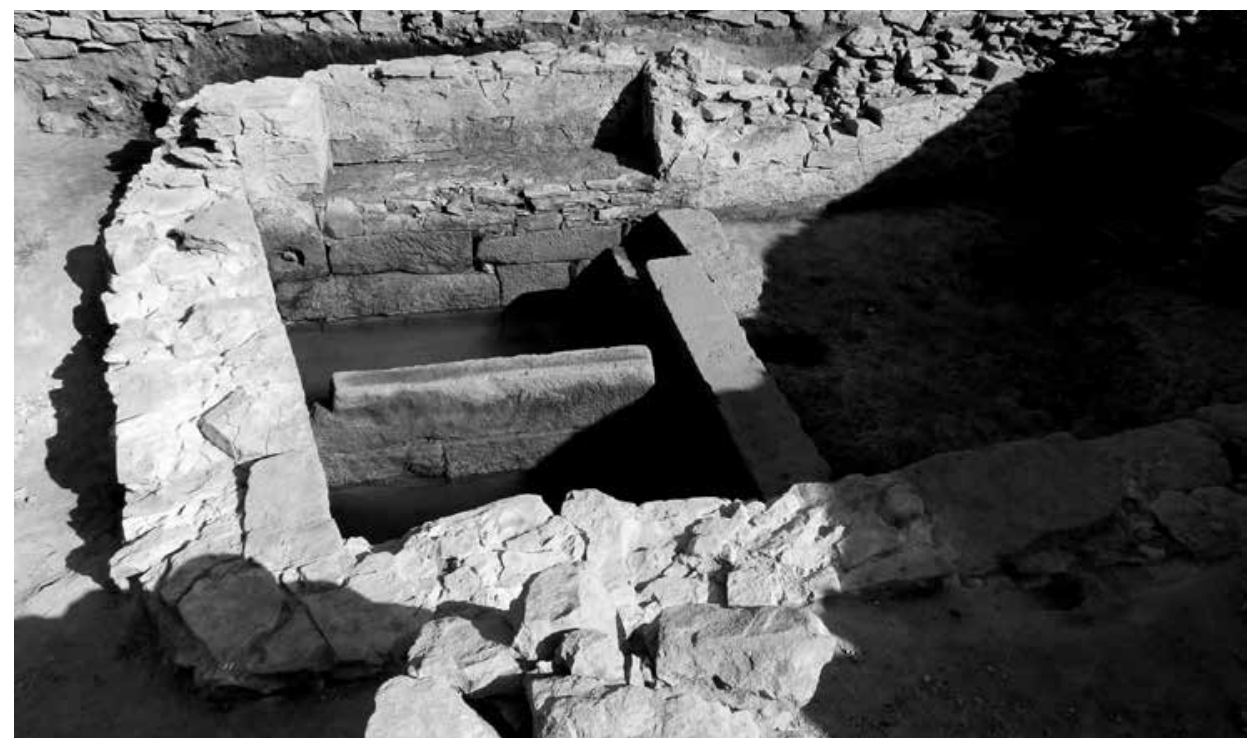

Obr. 8. Chrudim, Masarykovo náměstí. Západní část sklepa s rituální lázní (mikve). Pohled od jihu. Foto J. Frolík. Abb. 8. Chrudim, Masaryk-Platz. Westteil des Kellers mit rituellem Tauchbad (Mikwe). Blick von Süden. Foto J. Frolík. 


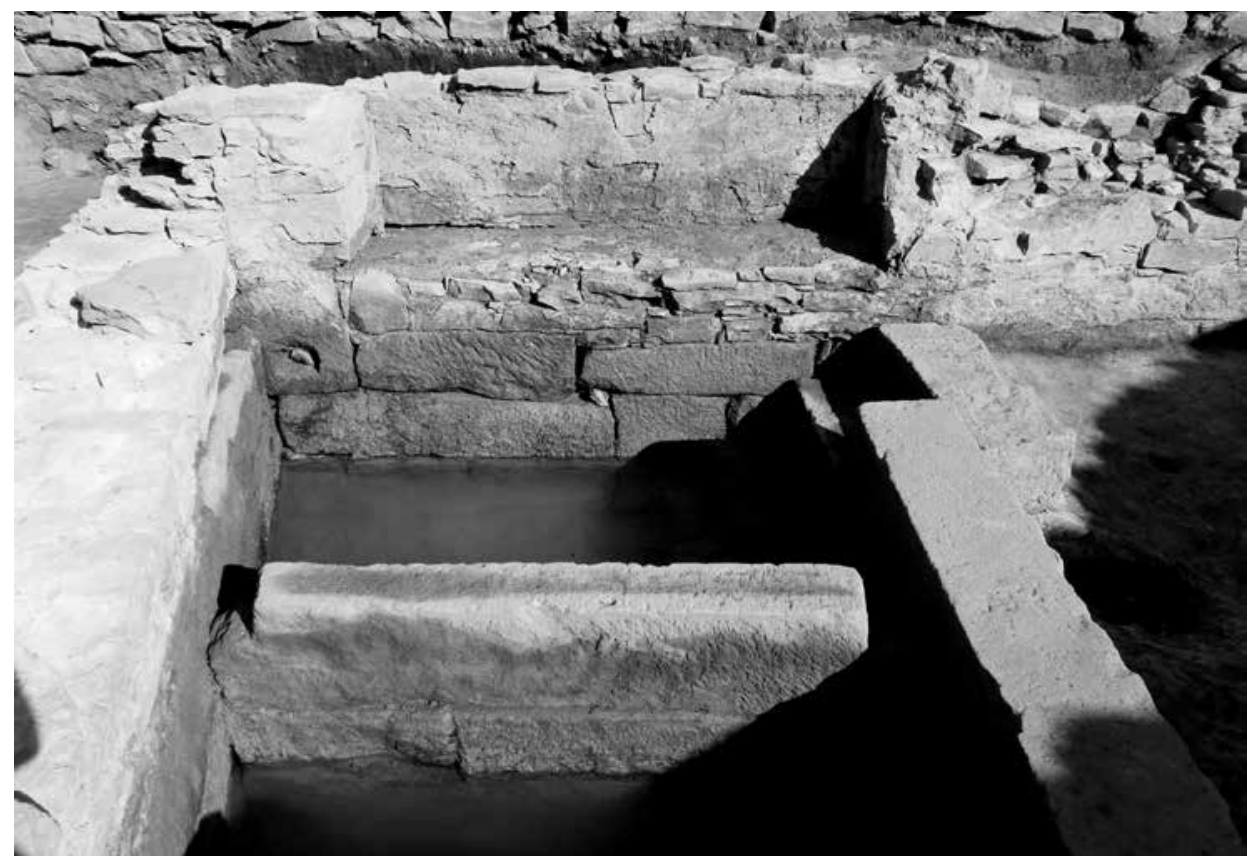

Obr. 9. Chrudim, Masarykovo náměstí. Rituální lázeň (mikve). Vzadu odkládací výklenek v obvodové zdi (zdivo 1968), vpravo vzadu schodiště do lázně (zdivo 1970); v popředí dělicí přepážka (zdivo 1971) s výřezy u stěn lázně. Pohled od jihu. Foto J. Frolík.

Abb. 9. Chrudim, Masaryk-Platz. Rituelles Tauchbad (Mikwe). Im Hintergrund Ablagenische in der Außenwand (Mauerwerk 1968), rechts im Hintergrund Tauchbadtreppe (Mauerwerk 1970); im Vordergrund Trennwand (Mauerwerk 1971) mit Aussparungen an den Beckenwänden. Blick von Süden. Foto J. Frolík.

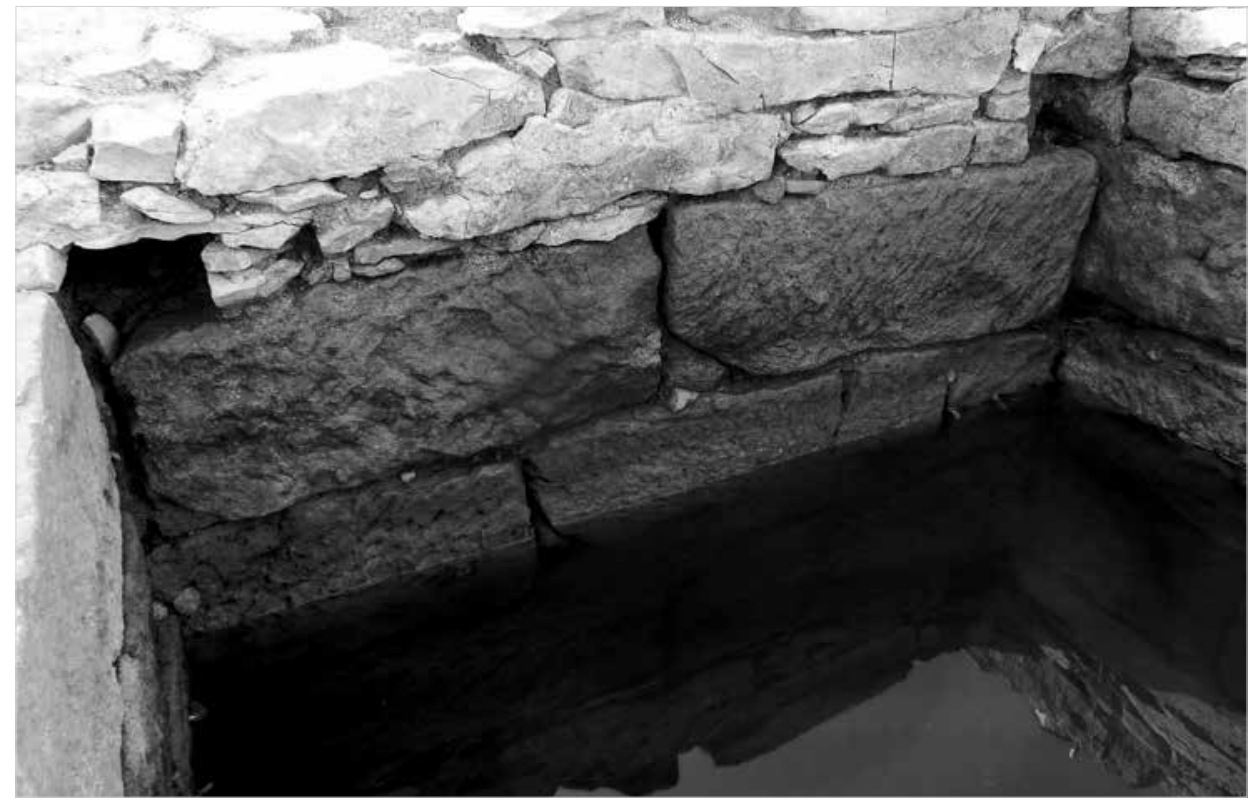

Obr. 10. Chrudim, Masarykovo náměstí. Rituální lázeň (mikve). Jižní stěna s lủžky pro trámy, které mohly nést poklop, zakrývající jižní díl lázně. Pohled od severovýchodu. Foto J. Frolík.

Abb. 10. Chrudim, Masaryk-Platz. Rituelles Tauchbad (Mikwe). Südwand mit Auflagerbetten für Balken, die eine den südlichen Teil des Tauchbades abdeckende Falltür tragen konnten. Blick von Nordost. Foto J. Frolík. 
do doby po požáru v roce 1850 . Mladší zdiva lze bez problémů ztotožnit s dochovaným plánem hospodářské budovy z roku 1858, uloženým ve Státním okresním archivu v Chrudimi.

Nález neobvyklého typu objektu vyvolal otázku jeho interpretace. Na základě analogií byla posléze nádrž identifikována jako židovská rituální lázeň - mikve. Obvykle je tvořena nádrží s přírodní vodou a slouží k rituálnímu očištění osob nebo předmětů. Měla by pojmout nejméně 762 litrů vody (jinde se uvádí interval 200 až 800 litrů) a měla by být dost hluboká, aby umožnila dospělému člověku úplné ponoření (i když třeba ve skrčené poloze). Musela mít přístupové schody (Harck 2014, 312). Ponoření do mikve je nezbytnou součástí konverze k judaismu (podstupují je muži i ženy). Rituálně se v mikve očištují některé druhy nádobí vyrobené nežidy před použitím v židovské kuchyni. Muži chodí do mikve zpravidla před významnými svátky. Rozšířený je zvyk chodit do mikve před začátkem šabatu. Mikve bývaly umistovány do sklepů domů sousedících s modlitebnami. Nádrž byla napájena podzemními prameny s přrirozeným př́ítokem vody (Harck 2014, 312). Tuto podmínku nález velmi dobře splňuje, protože nádrž je umístěna v zaniklém rameni Chrudimky, vyplněném písčitými nánosy filtrujícími vodu (za konzultace v této věci jsou autoři vděčni J. Maříkovi a M. Wallisové).

\section{Nálezy a jejich datování}

Pro datování vzniku sklepa a nádrže a také pro datování jejich zániku byly posouzeny keramické nálezy z uloženin vyplňujících již nefunkční nádrž - 6127 (sáčky 6005, 6288, 6526) a 6148 (sáčky 6371, 6535, 6714) - a uloženiny 5422 vyplňující zaniklý sklep (sáčky 5736, 6725). Již stratigraficky následné etapě náleží uloženina 5356 (sáčky 6290, 6466, 6594). Z doby existence sklepa pochází uloženina 5449 (sáčky 5742, 5864) a výplň objektu 2792 (sáček 6286). Žádné nálezy neposkytly kůlové jamky 2835 a 2859 a jáma 2894, které jsou starší než sklep. Kromě zlomků nádob a zlomků kachlů tvořily ostatní nálezy chronologicky necitlivé zlomky železných artefaktů (hřebíky), zvířecí kosti, uhlíky, zlomky mazanice a úlomky dřev.

Z uloženiny 5449 bylo získáno celkem 81 keramických zlomků, tvořících jednotně vyhlížející soubor převážně režné keramiky (obr. 11:1-13). Pouze čtyři zlomky jsou glazovány na vnitřní straně. Pokud lze určit, náleží fragmenty bezuchým hrncům nebo hrncům s uchem. Okrajové zlomky jsou jednoduše profilované a ohnuté, eventuálně ovalené. Keramika je převážně nezdobená, ojediněle se vyskytne zdvojená rytá linie, červeně malovaná linie nebo odsazení. Jedna nádoba měla na okraji plastickou úchytku. Jeden nezdobený zlomek pravděpodobně pochází z čelní stěny komorového kachle (část plastické lišty?). Soubor lze datovat do 16. století s tím, že některé jednotlivé prvky či složky mají počátek již ve století patnáctém. Způsob utváření souboru zůstane neznámý, pro jeho spíše náhlý zánik svědčí větší počet zlomků náležejících jedné nádobě (týká se pěti nádob). Z kůlové jamky 2792 v podlaze sklepa pochází torzo menší hrncovité nádoby s uchem (obr. 11:14), u níž chybí okraj. Torzo není zdobeno a je na vnitřní straně hnědožlutě glazováno. Datování odpovídá uloženině 5449. Celkově lze soubor charakterizovat jako pozdně středověký a blízký souboru keramiky z Husovy ulice (Frolík-Sigl 1990).

Z uloženiny 5422 vyplňující zaniklý sklep bylo získáno pouze jedenáct zlomků keramiky, z nichž se část neodlišuje od předchozího souboru (převážně režná a nezdobená keramika, ovalený okraj, glazura na vnitřní straně). Obsahuje však také zlomek z podhrdlí nádoby, zdobené na vnějši straně vícebarevnou glazurou, kterou lze datovat do 16. až 17. století.

Ze spodní uloženiny 6148 zásypu lázně/mikve bylo získáno 92 keramických fragmentů (obr. 12). Mezi keramickými tvary identifikujeme nádobu s uchem, trojnožku, mísu s talírovitým podkrajím nebo talír, mísu s uchem, pokličku a malou nádobku. Okraje jsou převážně prohnuté a zesílené. Výzdoba je jednoduchá, a to dvojitou rytou linií nebo plastickou lištou. Nadpoloviční většina ( 65 kusů) zlomků je glazována, převážně pouze na vnitřní straně. Zlomky talířů mají vnitřní stranu s malovaným ornamentem, který je převážně setřelý či špatně dochovaný (pravděpodobně v důsledku dlouhého pobytu ve vodním prostředí). Chronologicky je soubor podle některých znaků mladší než soubor z podlahy sklepa (mísy s talířovitým podokrajím a polychromní výzdobou na vnitřní straně, mísy s uchem posazeným souběžně s okrajem, trojnožka 


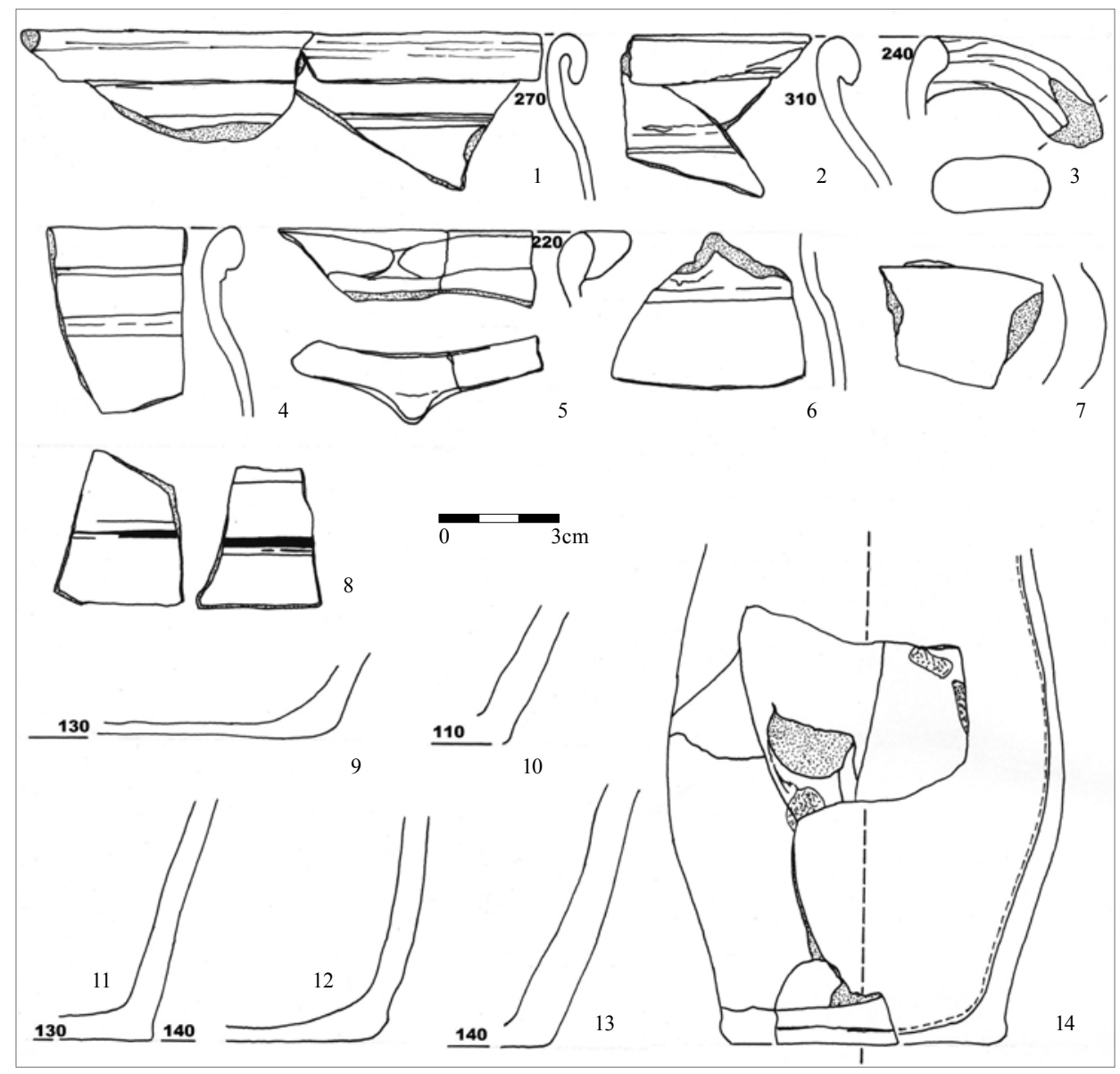

Obr. 11. Chrudim, Masarykovo náměstí. 1-13 - keramické fragmenty z podlahové vrstvy sklepa (uloženina 5449 ); 14 - torzo nádoby z kủlové jamky 2792 v podlaze sklepa. Červené malování vyznačeno černě, glazura šrafurou krátkými čárkami a čárkovaně po obvodu řezu. Kresba J. Frolík.

Abb. 11. Chrudim, Masaryk-Platz. 1-13 - Keramikfragmente aus der Fußbodenschicht des Kellers (Ablagerung 5449); 14 - Torso des Gefäßes aus Pfahlgrube 2792 im Kellerfußboden. Rote Bemalung schwarz gekennzeichnet, Glausur durch Schraffur mit kurzen Strichen und gestrichelt um den Schnittumfang. Zeichnung J. Frolík.

s držadlem rozšiřujícím se k okraji). Datování se pohybuje mezi pokročilým 16. nebo až 17. stoletím a jde o již raně novověký soubor. Nevýrazný je soubor z následující uloženiny 6127 , z něhož bylo vyzdviženo pouze čtrnáct keramických zlomků, převážně nezdobených. Tvarově lze určit hrnec a nádobu s uchem, většina zlomků nese glazuru na vnitřní straně. Jeden okraj je jednoduše profilovaný, druhý jednoduchý ven prohnutý. Č́st zlomků nese stopy po pobytu ve vodním prostředí. Datování zůstává široké, v rozmezí 15. až 17. století, prozrazující, že sem byla přemístěna zemina se starší keramikou. Nepočetný je také soubor z uloženiny 5356, která překryla nejen nádrž, ale také interiér sklepa. Získáno bylo pouze šestnáct zlomků keramiky obdobného charakteru jako soubor předchozí (ovalený či přehnutý okraj, nezdobené výdutě, glazura na vnitřní straně). Tvarově identifikujeme hrnec, nádobu s uchem a trojnožku. Část zlomků náleží redukční keramice. Datování opět zůstává v rámci širokého intervalu 15. až 17. století a zřejmě obsahuje príměs starších druhotně přemístěných zlomků.

Z uloženin 6148, 6127 a 5356 byly získány také fragmenty čtyř kachlů. Z uloženiny 6148 byl získán zlomek čelní vyhřívací stěny komorového římsového korunního kachle s motivem 


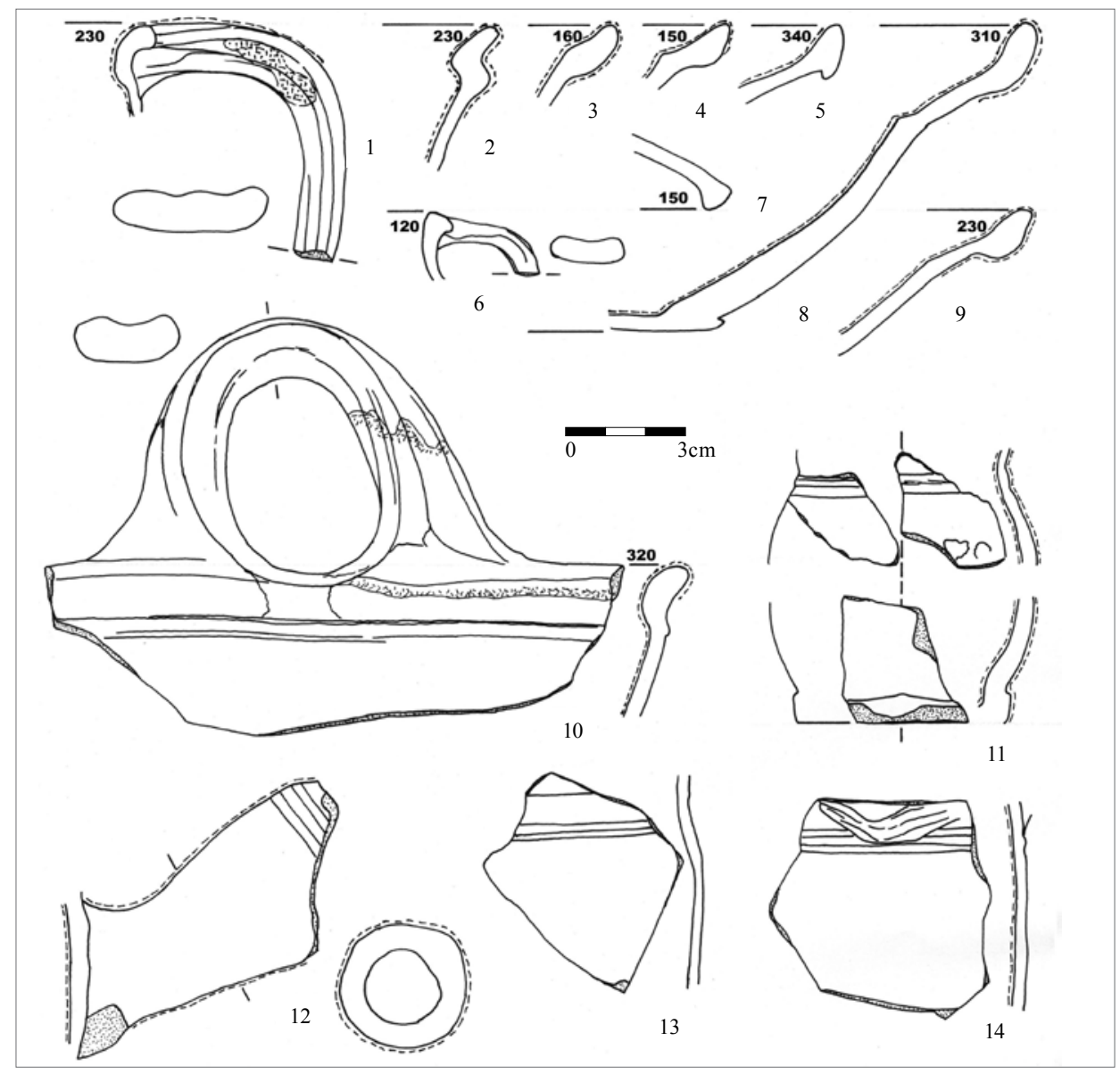

Obr. 12. Chrudim, Masarykovo náměstí. 1-14 - keramické fragmenty ze zásypové vrstvy lázně (uloženina 5148). Glazura vyznačena šrafurou krátkými čárkami a čárkovaně po obvodu řezu. Kresba J. Frolík.

Abb. 12. Chrudim, Masaryk-Platz. 1-14 Keramikfragmente aus der Verfüllungsschicht des Beckens (Ablagerung 5148). Glasur gekennzeichnet durch Schraffur mit kurzen Strichen und gestrichelt um den Schnittumfang. Zeichnung J. Frolík.

stylizované palmety. Podle analogických zlomků lze soudit, že horní okraj byl formován do podoby dvou malých lunet se stejným motivem jako na čelní stěně. Úplný tvar známe z již zmíněného souboru z objektu 10 v Husově ulici (Frolík-Sigl 1990; Frolík 2003, 70), který je datován do 16. století. Podobně provedený římsový korunní komorový kachel byl objeven v uloženině 6127. Dochovány jsou tři zlomky dokládající, že horní okraj byl proveden v podobě dvou lunet se stylizovanou palmetou. Na čelní stěně se nacházel velmi fragmentárně dochovaný motiv vinného hroznu. I tento motiv je doložen v chrudimském materiálu. Objevuje se na kachlích hrnčíre Jana Medka, který je písemně doložen pro období 1512-1538 (Frolík-Hazlbauer-Rückerová 1995), i když tento hrnčíř nepoužíval motiv se dvěma lunetami na horním okraji. Kachel je možné na tomto základě datovat do první poloviny 16. století (Frolík 2003, 61-62, 91). Další zlomek z téže uloženiny náleží komorovému kachli s kruhovým medailónovým zahloubením jako hlavním motivem. Výzdoba zbývající plochy se nedochovala. Provedením je tento kachel podobný nálezům z Husovy ulice - objektu 13, který je datován do 16. století (Frolík-Sigl 1996; Frolík 2003, 71). Poslední zlomek byl nalezen v uloženině 5356. Jde o rohový zlomek čelní 
vyhřívací stěny komorového kachle s kruhovým medailónovým zahloubením s neurčitelným motivem v něm. Rohová část zřejmě čtvercového kachle je zdobena pouze malým kruhovým vývalkem. Na rozdíl od výše zmíněných režných kachlů je tento zlomek zeleně glazován. Celý exemplář podobného kachle (v režném provedení) známe z Chrudimi - Filištínské ulice, z jímky IV, datované do 16. století (Frolík 2003, 82). Medailónové zahloubení zůstalo bez výzdoby. Podobný rohový motiv známe i z kachle s letopočtem 1691, jehož centrální motiv je proveden zcela odlišně (Frolík 2003, 22).

Celkové posouzení ukazuje na to, že sklep byl využíván nejméně v 16. století s možností vzniku stavby již dřive (pokročilé 15. století?). Keramika ze zánikových vrstev již obsahuje prvky kladené až do 17. století. Nepočetný kachlový materiál je starší (16. století), což lze vysvětlit delším užitím v kamnových tělesech, a proto opožděným přemístěním do odpadu.

\section{6 Židé v Chrudimi}

Jak již bylo zmíněno, nejsou pro období před rokem 1708 o zkoumaném prostoru k dispozici písemné zprávy. Přítomnost Židů můžeme odvozovat pouze ze širších okolností. Na jejich prrítomnost ve městě již ve 14. století ukazuje pojmenování Židovská ulice ve zlomku berního rejstř́iku z let 1399-1401 a pak název „na Židovském kopci“, který se objevuje v městských knihách od doby pohusitské (Langová-Růžičková 2006, 3). S konkrétní osobou se setkáváme v roce 1511, kdy Žid Kapř́ík získal tři pruty pole a následně je prodal Jakubovi Řepíčkovi. V roce 1556 je doložena Židovka Ester z Chrudimi, která dovážela a v Chrudimi prodávala cizokrajná vína. Další jmenovitě uvedenou osobou je Žid Jakub Mandl v roce 1627 (Langová-Růžičková 2006, 3). Podle soupisu poddaných z roku 1651 se v Chrudimi uvádějí dvě židovské rodiny po čtyřech členech (Růžičková-Langová 2006, 53), obě bydlící v dnešní Břetislavově ulici. Berní rula zmiňuje k roku 1654 tři Židy starší 20 let. V roce 1656 se městská rada usnesla, že v Chrudimi nesmí pobývat žádný Žid s výjimkou Abrahama Hippena (psán i Hyppen), který je v Chrudimi doložen již v roce 1636 . V roce 1660 se usnesení opakuje a tentokrát se vztahuje i na Abrahama Hippena (Langová-Růžičková 2006, 3). Stalo se tak na základě (obvyklého?) nařčení z požáru města, zavlečení moru a lichvy. Další téměř století se s Židy v Chrudimi nesetkáváme. Chrudimská obec bránila jejich usazování ve městě až do roku 1765, kdy jim bylo povoleno zřídit ve městě sklad tabáku (Růžičková-Langová 2006, 53). Sčítání v letech 1783 a 1793 eviduje v Chrudimi devět, respektive deset osob, což snad odpovídá dvěma rodinám, které jsou zachyceny dále k rokům 1825 a 1837 (Langová-Růžičková 2006, 5). Výrazněji začal počet Židů narůstat až po úplné emancipaci na základě ústavy z roku 1867.

\section{Diskuse}

Z historických údajů lze vyvodit, že nalezená lázeň musí patřit bud' do období před rokem 1656, resp. 1660, nebo po roce 1765 . V mezidobí Židé v Chrudimi nebyli. Stratigraficky je nádrž umístěna v nejstarší doložené kamenné stavbě na zkoumaném úseku staveniště. Archeologické nálezy z vrstvy uložené na podlaze sklepa ukazují, že sklep byl užíván v 16. století s možným přesahem ještě do století předcházejícího. Zánik naznačují nálezy z uloženin, kterými byla zavezena nádrž a posléze i sklep a které obsahují keramické zlomky kladené do 17. století. Tyto údaje jsou v dobrém souladu s písemnými zprávami o vyhnání Židů v důsledku usnesení z let 1656 a 1660. Obě data představují mezní hranici; sám dům se sklepem s lázní mohl zaniknout i o něco dříve, např̀. v důsledku událostí třicetileté války. Archeologické datování se tak míjí s dochovanými písemnými zprávami o zástavbě v těchto místech, které jsou mladší (nejstarší z roku 1708). Starší stavby by mohl naznačovat údaj o pustém místě pro vystavění domku. Jako „pusté místo“ se v městských knihách označují v městském jádru parcely, na nichž již zástavba existovala, ale byla zničena $\mathrm{v}$ důsledku válečných událostí nebo jiné katastrofy (požáru). Typickým př́íkladem může být blok domů v Hradební ulici, kde za třicetileté války zanikly s jedinou výjimkou všechny domy a „pustá místa“ byla znovu zastavována několik desetiletí (Frolík-Musil 2010, 12-16). 
Datování do 16. století určuje lázeň/mikve jako jednu z nejstarších u nás. V posledních letech byly zpř́istupněny či obnoveny lázně/mikve v několika lokalitách (Dobruška, Boskovice). Často schází údaj o jejich skutečném stáří, protože nelze př́imočaře spojovat stáŕí budovy a stáŕí lázně. V Boskovicích domky židovského ghetta pocházejí převážně až z doby po požáru v roce 1823 (Samek 1994, 102). V Dobrušce jsou dochované židovské památky až ze 17. století (1675Poche 1977, 274). Nejasně je datována mikve ve sklepích pod Pinkasovou synagogou v Praze. Synagoga byla postavena v roce 1535 a uvažuje se, že lázeň byla zř́izena již v této době (Vlček 1996, 551). Na Chrudimsku je mikve doložena v Heřmanově Městci, kde byla nejpočetnější židovská komunita a stála zde synagoga, kterou pravděpodobně také využívali chrudimští Židé jako nejbližší dosažitelné místo náboženských obřadů. Dochovaná synagoga byla postavena až v roce 1760 (Růžičková-Langová 2006, 39-41). Nedaleko byla doložena lázeň/mikve. Archeologicky byly objeveny části dvou nádrží, ale stáří zůstává neznámé (nepublikovaný výzkum J. Šulcové, NPÚ ÚOP v Pardubicích). Další mikve na Chrudimsku se dochovala v obci Přestavlky. Nachází se v samostatném domku a na místě starší dřevěné mikve byla vybudována v roce 1858 (Růžičková-Langová 2006, 61).

Lázně/mikve známe také ze sousedních zemí. Německé př́iklady ukazují na opatrný přístup k jejich datování. Mikve v Kolíně nad Rýnem byla podle keramiky v zásypech datována již do 9. století, dendrochronologie posunula datování do 13. století (Harck 2014, 316). Mikve ve Speyeru byla datována na základě písemné zmínky a architektonických detailů stavby, v níž je umístěna, do počátku 12. století. Archeologický výzkum doložil její datování do pokročilého 14. století (Harck 2014, 318-319). Velmi staré př́klady z území mimo Palestinu byly objeveny ve východním Středomoří. V židovské čtvrti na ostrově Délos je několik lázní dochováno ve sklepích domů. Židovská komunita zde žila od 2. století př. n. 1. a je doložena až do 2. století n. 1 . (Zaphiropoulou 2007, 42-43). Lze nalézt ještě řadu dalších analogií (jen z Německa je doloženo 47 nálezů - Harck 2014, 313), ale pro naše pozorování stačí závěr, že objevená lázeň/mikve fungovala minimálně v části 16 . století a v první polovině 17 . století a je jedním z mála dobře datovaných objektů tohoto účelu na našem území.

\section{Závěr}

Záchranný archeologický výzkum na staveništi podzemních garáží u hotelu Bohemia v Chrudimi je (zatím) nejvýznamnějším př́inosem k poznání chrudimských středověkých předměstí a díky příznivé shodě okolností dovolil poznat vývoj domovní zástavby a přilehlých částí parcel pro etapu 13.-20. století. Může být považován za jistou splátku za rozsáhlý únik archeologických informací o předměstích v 70. a 80. letech 20. století, kdy došlo k jejich plošné asanaci. Neočekávaným nálezem je rituální lázeň - mikve, která obrátila pozornost na prŕitomnost židovské komunity ve městě, jež v důsledku malého počtu jinak uniká archeologické evidenci. Mikve je zároveň nejstarším podobným dochovaným objektem v Pardubickém kraji a s velkou pravděpodobností jedním $\mathrm{z}$ nejstarších na našem území. $\mathrm{Z}$ tohoto důvodu byl podán návrh na zapsání za kulturní památku.

\section{Literatura}

FLORIÁN, Č., 1914: Nález historické keramiky v Chrudimi, PA XXVI, 67-69.

- b. d.: Topografie města Chrudimi, rukopis ulož. v osobním fondu „Čeněk Florián“ ve Státním okresním archivu v Chrudimi.

FROLÍK, J., 1980: Archeologické nálezy z prostoru továrny Transporta, Zpravodaj Krajského muzea východních Čech 7, 65-78.

- 2003: Kachle Chrudimska. Sbírky Regionálního muzea v Chrudimi 5/II. Chrudim.

- 2006: Chrudim - raně středověké centrum jižní části východních Čech (Archeologie a 950. výročí první písemné zmínky) - Chrudim - frühmittelalterliches Zentrum des südlichen Teils Ostböhmens (Archäologie und 950. Jahresgedächtnis der ersten Erwähnung), AH 31, 7-19. 
- 2012: Archaeological examination of medieval towns in Bohemia (An overview by an archaeologist), Analecta Archaologica Ressoviensis 7, 67-109.

FROLÍK, J.-HAZLBAUER, Z.-RÜCKEROVÁ, A., 1995: Chrudimský hrnčířský rod Medků a jeho kamnářské výrobky - Töpfergeschlecht Medek von Chrudim und die Kachelnerzeugnisse, AH 20, 523-538.

FROLÍK, J.-MUSIL, J., 2010: Záchranný archeologický výzkum v Chrudimi, Hradební ulici, v roce 2006, Chrudimský vlastivědný sborník 14, 3-28.

FROLÍK, J.-PECINOVSKÁ, M.-VEPŘEKOVÁ, J., 2014: Neolitický dlouhý dům z Chrudimi - Masarykova náměstí. Předběžná zpráva - Ein neolithisches Langhaus aus Chrudim - Masaryk-Platz. Verläufiger Bericht. In: Archeologie východních Čech - Supplementum 1. Sborník k poctě Jiřího Kalfersta, 78-86. Hradec Králové.

- 2014a: Záchranný výzkum při stavbě podzemních garáží u hotelu Bohemia v Chrudimi - Rettungsgrabung beim Bau der Untergrundgaragen des Hotels Bohemia in Chrudim. In: Zprávy ČAS - Supplément 93. Archeologické výzkumy v Čechách 2013. Sborník referátů z informačního kolokvia, 47-48. Praha.

FROLÍK, J.-SIGL, J., 1984: Předběžná zpráva o záchranném archeologickém výzkumu v Chrudimi na Kateřinském předměstí, Zpravodaj Krajského muzea východních Čech 11, 72-73.

- 1990: Soubor pozdněstředověké keramiky z Chrudimi - Husovy ulice - A group of late Mediaeval pottery from the town of Chrudim (Husova street), Studies in Post-Medieval Archaeology 1, 269-284.

- 1995: Chrudimsko v raném středověku. Vývoj osídlení a jeho proměny - Chrudim Region (East Bohemia) in the Early Middle Ages. Development of Settlement and Related Structural Changes - Das Chrudimer Land im Frühmittelalter. Die Entwicklung der Besiedlung und seine strukturellen Probleme. Hradec Králové.

- 1996: Počátky Kateřinského předměstí z pohledu archeologie, Chrudimský vlastivědný sborník 1, 3-28.

- 1997: Die Chrudimer Siedlung biem H1. Kreuz und ihre Bedeutung für die Anfänge der Stadt. In: Život v archeologii středověku, 176-184. Praha.

- 1998: Chrudim v pravěku a středověku. Obrazy každodenního života - Chrudim in prehistory and the Middle Ages. Pictures of everyday life - Chrudim in der Urgeschichte und im Mittelalter. Bilder aus dem Alltagsleben. Chrudim.

- 1998a: Chrudim - od slovanského hradiště k vrcholně středověkému městu - Chrudim - from the Slavic hillfort to the town of High Middle Ages. In: Kultura Średniowiecznego Śląska i Czech. „Rewolucja“ XIII wieku. Międzynarodowe sympozjum 3, 113-120. Wrocław.

HARCK, O., 2014: Archäologische Studien zum Judentum in der europäischen Antike und dem zentraleuropäischen Mittelalterlicher. Petersberg.

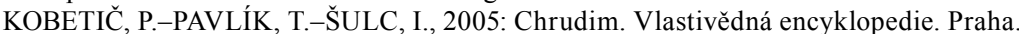

LANGOVÁ, A.-RŮŽIČKOVÁ, R., 2006: Židé v Chrudimi. Chrudim.

POCHE, E., 1977: Umělecké památky Čech 1. A-J. Praha.

RŮŽIČKOVÁ, R.-LANGOVÁ, A., 2006: Stopy Židů v Pardubickém kraji - Traces of the Jews in the Pardubice Region. Pardubice.

SAMEK, B., 1994: Umělecké památky Moravy a Slezska 1. A-I. Praha.

ŠUŠOLOVÁ, J.-HADACZ, R., 2013: Chrudim, hotel Bohemia 2013. Chemické, fyzikální a mikromorfologické zhodnocení odebraných vzorků zemin, rkp. ulož. v archivu ARÚ AV ČR, Praha, v. v. i., TP-2013-2766.

VLČEK, P., 1996: Umělecké památky Prahy. Staré Město. Josefov. Praha.

ZAPHIROPOULOU, F., 2007: Delos. Monuments and Museum. Athens.

ZAVŘEL, J., 2013: Chrudim 2013. Podzemní parking hotelu Bohemia. Vyhodnocení geologických poměrů archeologické lokality, rkp. ulož. v archivu ARÚ AV ČR, Praha, v. v. i., TP-2013-2753.

\section{Zusammenfassung}

\section{Der Fund eines rituellen jüdischen Tauchbades - einer Mikwe - in Chrudim. Die archäolo- gische Rettungsgrabung in der Johannesvorstadt im Jahr 2013}

Im Jahr 2013 erfolgte in der ostböhmischen Stadt Chrudim auf der Fläche der unterirdischen Garagen des Hotels Bohemia eine archäologische Rettungsgrabung (Abb. 1). Dabei bot sich die Möglichkeit, über eine Fläche von fünf Parzellen der mittelalterlichen Vorstadt eine Grabung durchzuführen (Abb. 2-4). Das Grundstück befindet sich in der holozänen Flussau der Chrudimka. Den Untergrund bilden von Bleicherde (Bodentyp Podsol) überdeckte fluviale 
Sedimente. Im frühen Mittelalter war das Gelände durch Hochwasserflussbette gegliedert. Die so entstandenen Senken haben sich mit Schlamm- und Lehmsedimenten verfüllt und wurden in der Neuzeit mit Aufschüttungen ausgefüllt (Šušolová-Hadacz 2013; Zavřel 2013).

Auf der untersuchten Fläche hat man überraschenderweise eine urzeitliche Besiedelung (Neolithikum, Bronzezeit) und zahllose Funde aus dem 9.-12. Jahrhundert entdeckt (FrolíkPecinovská-Vepřeková 2014; 2014a). Angefangen mit dem 13. Jahrhundert war die untersuchte Fläche kontinuierlich besiedelt, schriftliche Berichte informieren indes erst ab 1708 über eine Bebauung. Den schriftlichen Berichten nach handelte es sich insgesamt um fünf Immobilien (Konskriptinosnummern 37/IV bis 39/IV, 52/IV und 53/IV). Alle Immobilien sind 1850 abgebrannt. In den sechziger Jahren des 20. Jahrhunderts wurde die Bebauung abgerissen. Durch die archäologische Grabung wurde nachgewiesen, dass eine Bebauung aus Stein bereits im 15. Jahrhundert erfolgte, deren Gliederung eine im 18. und 19. Jahrhundert belegte Verteilung auf einzelne Immobilien kopierte. Die älteste Bauetappe wurde aus Pläner auf Lehm errichtet und wies vor dem Brand von 1850 zwei bis drei Umbauten auf. Auf den benachbarten Gehöften wurde die übliche Ausstattung entdeckt (Brunnen, Abwassergruben, Öfen). Die Funde deuten darauf hin, dass die Bewohner der späteren Immobilie mit der Konskriptionsnummer 52/IV das Töpferhandwerk ausübten. Es gab auch zahlreichen Abfall aus der Knochenbearbeitung. Keramik- und Glasfunde zeigen auf, dass sich die Sachkultur der Vorstadt und der Innenstadt im Zeitraum 15. bis 18. Jahrhundert nicht voneinander unterschied, und zwar auch nicht was das Vorkommen von weniger gängigen Funden betraf (Steingut, Keramikimporte, bemaltes Glas).

Unsere Aufmerksamkeit konzentrierte sich auf den am östlichen Rand der Grabung entdeckten Keller (Abb. 6). Sein Mauerwerk wurde aus 0,6-0,65 m breiten Bruchplänern gemauert. Die erhalten gebliebenen Maße betragen 6,1 $\times 4,25 \mathrm{~m}$. In der nordöstlichen Ecke wurde der Torso einer Steinschwelle entdeckt (Mauerwerk 1973), auf der ein umgestürzter Pfosten der Türlaibung lag. In östliche Richtung wurden zwei Treppenstufen freigelegt (Mauerwerk 1980). Der Fußboden des Kellers bestand aus der sekundär tiefergelegten Oberfläche des Untergrunds (Ablagerung 5491). Dem Charakter der einzelnen Ablagerungen nach gibt es den Anschein, dass es in dem Zeitraum, als der Keller existierte, nur Ablagerung 5449 in einer maximalen Stärke von $0,1 \mathrm{~m}$ gab. In den Fußboden wurden mehrere kleine Pfahlgruben eingetieft. In einer von ihnen (Aushub 1792) war ein Gefäß eingelassen. Die Höhe der Ablagerungsschichten füllten den Innenraum des bereits verschwundenen Kellers aus (5356, 5394, 5422, 5423, 6281, 6298, 6299, 6305, 6306).

Im Westteil des Kellers entdeckte man ein Wasserbecken aus großformatigen Sandsteinblöcken oder Sandsteinplatten (Abb. 6, 7). In der nördlichen Kellerwand oberhalb des Beckens befand sich eine Ablagenische mit den Maßen 1,85×0,5-0,55 m (Abb. 8, 9). Die Innenmaße des Beckens betrugen 2,9-3,1 ×1,55-2,2 m. Das aus zwei Teilen bestehende Becken war durch eine Trennwand aus Sandsteinblöcken und eine großformatige Platte unterteilt (Mauerwerk 1971). Die Breite der Trennwand beträgt 0,2 m. An den Seiten befanden sich in der Krone der Trennwand Aussparungen mit den Maßen 0,15×0,15 m (Abb. 9, 10). Das Becken war in der nordöstlichen Ecke über eine Treppe zugänglich, die aus drei Sandsteinstufen bestand (Abb. 9). An drei regelmäßig gemauerte Stufen schloss noch eine vierte an, bei der es sich um die niedrigste Stufe handelte, die sich aus zwei unregelmäßigen Blöcken zusammensetzte. Die Gesamttiefe des Beckens beträgt 0,93-1,01 m. Nachdem das Becken nicht mehr genutzt worden war, wurden beide Beckenteile mit Lehmschichten verfüllt, denen Steine beigemischt waren, deren Stärke $0,9 \mathrm{~m}$ überstieg (Ablagerungen 6127 und 6148). Anhand von Analogien wurde das Becken als Mikwe, d.h. als rituelles jüdisches Tauchbad identifiziert. Üblicherweise besteht eine Mikwe aus einem mit lebendigem Wasser gefüllten Becken, das mindestens 7621 fassen und so tief sein soll, damit ein Erwachsener ganz darin untertauchen kann, etwa auch in gekrümmter Körperhaltung. Sie musste mit Zugangstreppen versehen sein (Harck 2014, 312).

Für die Datierung der Entstehung von Keller und Becken und deren Untergang wurden die Keramikfunde in den Ablagerungen (6127 und 6148), mit denen das nicht mehr genutzte Becken verfüllt war, sowie die in Ablagerung 5422, mit denen der Keller verfüllt war, ausgewertet. 
Ablagerung 5356 gehört bereits zur stratigraphisch anschließenden Etappe. Aus der Zeit, als der Keller noch existierte stammen Ablagerung 5449 und die Verfüllung von Objekt 2792. Aus Ablagerung 5449 wurden insgesamt 81 Keramikbruchstücke gewonnen, die einen einheitlichen Komplex aus überwiegend unglasierter Keramik bilden (Abb. 11:1-13). Der Komplex kann ins 16. Jahrhundert datiert werden, wobei der Anfang mancher Einzelstücke bereits im 15. Jahrhundert liegt. Aus Pfahlgrube 2792 im Kellerfußboden stammt der Torso eines kleineren topfartigen Gefäßes mit Henkel (Abb. 11:14). Aus Ablagerung 5422 der Kellerverfüllung wurden lediglich 11 Keramikbruchstücke gewonnen, die in den Zeitraum 16. bis 17. Jahrhundert datiert werden können. Aus der unteren Ablaberung 6148 der Verfüllung der Mikwe wurden 92 Keramikfragmente gewonnen (Abb. 12), deren Datierung sich zwischen dem fortgeschrittenen 16. und dem 17. Jahrhundert bewegt. Bei ihnen handelt es sich bereits um einen neuzeitlichen Fundkomplex. Der aus der folgenden Ablagerung 6127 gewonnene Komplex ist von nur geringer Bedeutung (14 Keramikbruchstücke). Seine Datierung verbleibt in der Spanne zwischen dem 15. und 17. Jahrhundert, was verrät, dass hier Erdreich mit älterer Keramik hin verlagert worden war. Ähnlich verhält es sich mit dem Fundkomplex aus Ablagerung 5356, die nicht nur das Becken bedeckte, sondern auch den Innenraum des Kellers (16 Keramikbruchstücke).

Wie bereits erwähnt, existierten über den untersuchten Bereich für die Zeit vor 1708 keine schriftlichen Berichte. Die Präsenz von Juden können wir lediglich anhand der breiteren Umstände ableiten. Darauf deutet im 14. Jahrhundert bereits die Aufführung einer Judengasse in einem Fragment des Steuerregisters aus den Jahren 1399-1401 hin. Einer konkreten Person begegnen wir im Jahr 1511 und weitere zwei sind in den Jahren 1556 und 1651 belegt. In einem Untertanenverzeichnis aus dem Jahr 1651 werden in Chrudim zwei jüdische Familien mit je vier Mitgliedern aufgeführt (Růžičková-Langová 2006, 53). Die Steuerrolle für Böhmen (Berní rula) erwähnt 1654 drei Juden, die älter als zwanzig Jahre waren. Im Jahr 1656 beschloss der Stadtrad, dass sich in Chrudim keine Juden aufhalten dürfen. Dieser Beschluss wurde im Jahr 1660 wiederholt (Langová-Růžičková 2006, 3). Die Gemeinde Chrudim verhinderte bis zum Jahr 1765, dass Juden sich in der Stadt niederlassen konnten (Růžičková-Langová 2006, 53). Die Zahl der Juden begann erst nach der vollständigen Emanzipation im Jahr 1867 deutlicher anzuwachsen.

Aus den historischen Angaben lässt sich ableiten, dass die entdeckte Mikwe entweder in die Zeit vor 1656/1660 oder nach 1765 datiert gehört. Stratigraphisch befindet sich das Becken im ältesten belegten Steinbau des untersuchten Baustellenabschnittes. Die aus den auf dem Kellerfußboden abgelagerten Schichten stammenden archäologischen Funde deuten darauf hin, dass der Keller im 16. Jahrhundert mit einem möglichen Überhang in das vorhergehende Jahrhundert genutzt wurde. Sein Untergang wird durch die Funde angedeutet, die aus den Ablagerungen stammen, mit denen das Becken und schließlich auch der Keller zugeschüttet wurden und Keramikfragmente enthalten, die ins 17. Jahrhundert datiert werden. Diese Angaben decken sich gut mit den schriftlichen Berichten über die Vertreibung der Juden infolge der Beschlüsse aus den Jahren 1656 und 1660.

Die Datierung ins 16. Jahrhundert bestimmt die Mikwe als eine der ältesten Tauchbäder Böhmens. In der Region Chrudim ist eine weitere Mikwe in Heřmanův Městec (Hermannstädtel) belegt, wo die zahlenmäßig stärkste jüdische Gemeinde war und sich eine Synagoge befand. Sie wurde in der erhaltenen Form erst im Jahr 1760 gebaut (Růžičková-Langová 2006, 39-41). Archäologisch wurden die Teile von zwei Becken entdeckt, deren Alter jedoch unbekannt blieb (unveröffentlichte Grabung von J. Šulcová). In der Region Chrudim ist in der Gemeinde Přestavlky eine weitere Mikwe erhalten geblieben. Sie befindet sich in einem kleinen, allein stehenden Haus und wurde im Jahr 1858 an der Stelle einer älteren Mikwe aus Holz gebaut (RůžičkováLangová 2006, 61).

Die archäologische Rettungsgrabung auf dem Bauplatz der unterirdischen Garagen des Hotels Bohemia in Chrudim stellt einen wichtigen Beitrag dazu dar, die Kenntnisse über die mittelalterliche Vorstadt Chrudims zu erweitern und erlaubte es, die Entwicklung der Häuserbebauung und der Parzellen im 13.-20. Jahrhundert in Erfahrung zu bringen. Das rituelle Tauchbad, die Mikwe, ist ein unerwarteter Fund, der die Aufmerksamkeit auf die Präsenz einer jüdischen 
Gemeinschaft in einer Stadt richtete, in der sie sonst infolge der geringen Anzahl von Personen, der archäologischen Dokumentation entgeht. Die Mikwe ist zugleich das älteste vergleichbare erhaltene Objekt im Kreis Pardubice und mit hoher Wahrscheinlichkeit auch eines der ältesten auf dem Gebiet der Tschechischen Republik.

PhDr. Jan Frolík, CSc., Archeologický ústav AV ČR, Praha, v. v. i., Letenská 4, 11801 Praha 1, Česká republika,frolik@arup.cas.cz

Mgr. Monika Pecinovská, Archeologický ústav AV ČR, Praha, v. v. i., Letenská 4, 11801 Praha 1, Česká republika, pecinovska@arup.cas.cz

Jana Vepřeková, Archeologický ústav AV ČR, Praha, v. v. i., Letenská 4, 11801 Praha 1, Česká republika, jankovitz@seznam.cz 
